\title{
Investigation of volatility and spillover in foreign exchange return in Indian Chinese \& Malaysian market
}

\author{
Amritkant Mishra * \\ Department of HSS, Jaypee Institute of Information Technology University, Noida, India \\ *Corresponding author E-mail: amritkant@gmail.com
}

\begin{abstract}
In this paper it is tried to make the comparison the foreign exchange return volatility in the three emerging economies of Asia. It is also endeavored to investigate the return co-movement and the volatility spillover between the foreign exchange markets of India, China and Malaysia with reference of US dollar, Indian Rupees, Chinese Yuan and Malaysian Ringgit in each other foreign exchange market to. The daily data have collected from Federal Reserve data base from April 2012 to March 2017. For analysis MGARCH model, the GARCH DCC as well as VAR model applied. The empirical result of volatility spillover effect shows that in Indian and Malaysian foreign exchange market the US dollar seems as shock transmitter. It also shows that the influence of US dollar in Chinese foreign exchange market is very low as compare to the Indian and Malaysian exchange rate market. In Chinese market Malaysian ringgit is dominant currency and it transmits the shocks to the US dollar. The conditional volatility result shows that among all the foreign exchange market, Indian market has high volatility return of foreign currency as compare to other market.
\end{abstract}

Keywords: FOREX - Foreign Exchange Market; Volatility; GARCH; VAR; MGARCH.

\section{Introduction}

In current dynamic economic situation the volatility has become a relevant issue for all the economy is concerned. In present globalised economic time none of the economy in the world is isolated. Every nation in the world has an economic relation with other nation. The trade relationship and much economic transaction between nations is continuous growing in the world and this is also leading the volatility in the exchange rate of each other country. Many economists have given their own argument about volatility. Volatility can be classified in two sub part. First component of volatility could be predictable component and other is unpredictable component. We can model the volatility on the assumption of predictable phenomenon. According to the Knight's (1921) volatility is types of risk in that it provides a measure of the possible variation or movement in a particular economic variable or some function of that variable over some period of time. Volatility in exchange rate may take place due many factors such as fundamental expectation about the economy secondly the policy initiatives taken by the government and lastly the speculation by the arbitragers which is not related to the current or future fundamental expectation of the economy. The exchange rate is defined by the relative price of currencies of different country. There are many factors which can impact the exchange rate of the trading nation, such as volume of import export, capital movement, governmental policy, international investment portfolio and most relevant is current or expected economic situation.

This study is to investigate the exchange rate co movement in terms of different country's currencies and also the volatility spillover effect. We have taken the world's two largest economy India and China as well as Malaysia. The volatility co movement helps us to understand the how the exchange rate of a country is co varying in terms of different nation's currency. The spillover effect helps to understand the transfer the shock from one market to other market. The rest of the paper is organized as follows. Section II reviews the literature, in Section III explains the methodology. The results of empirical estimation are included and the economic interpretation of the results is given in Section IV. Finally Section V Concludes.

\section{Review of literature}

The first initiatives taken by the Engle for capturing the volatility. The model developed for measuring the volatility is ARCH in (1982) and after some time, GARCH model was developed by ollerslev (1986), after this model there were number extended model was developed. The extension version of $\mathrm{ARCH}$ and GARCH model like EGARCH Suggested by Nelson (1991), the GJR model by Glosten, Jaganathan and Runkle(1992). The entire above model were useful for univariate analysis for multivariate analysis the multi GARCH model. The first model of this type was the Constant Conditional Correlation (CCC-) model introduced by Bollerslev (1990). The dynamic Conditional Correlation (DCC) GARCH model was propounded by the Engle and Sheppard in (2011) which is supposed to be the best model for multivariate GARCH modeling. There are many research articles, which have applied basic GARCH modeling to capture the volatility. Bauwens et al. (2006) modeled the Norwegian kroner volatility by using the EGARCH. Laurent and Neely (2012) modeled the volatility in an exchange rate by conversing intraday periodicity, autocorrelation and discontinuities in prices. Hviding et al. (2004) investigated larger international reserves decrease the exchange rate volatility through $\mathrm{GARCH}$ approach. As per multivariate modeling is concerned the relation between several European currencies, and the euro have been analyzed by Dijt, Munandar 
and Hafner (2005). Perez-Rodriguez (2006) found that relevant volatility spillovers between the euro, yen and the pound and that correlations between the euro and the pound is high PerezRodriguez applied GARCH DCC for his investigation. For finding the best hedge ratio of currency exchange risk exposure. Hautschand and Inkman (2003) applied the DCC model. Beine, Laurent \& Lecourt in (2003), investigated the credibility of central bank intervention on the volatility of yen vs euro. In 2005 Badrinath and Apte, investigated the volatility spill over across the stock market, call Money market and the foreign exchange market of India using multivariate EGARCH model. The author found that asymmetric volatility spillover across these markets the returns in the foreign exchange market of India is reverting towards its mean. Behera (2011) signifies that Non Deliverable-Forward market (NDF) Shocks and volatilities influence the on shore markets. Saha and Chakrabarti investigated volatility spillover with no asymmetric impact between stock to exchange rate market and from exchange rate to stock in 2011. Ahmed (2012) had applied GARCH models and found that the money supply, price level and current account as main factor of exchange rates volatility in Sudan. Munazza Jabeen and Saud Ahmad Khan (2013) found that, exchange rate volatility in Pakistan results from real shocks rather than external shock nominal shocks. Anuradha Patnaik (2013) found that the prevalence of very high level of volatility and volatility clustering in each of these exchange rates in India and also the volatility spillover interpreted from the DCCs amongst these rates, is evident and asymmetric over a period of time. Wann-Jyi Horng and Ju-Lan Tsai found that, Brazilian and Australian exchange rate markets do have the asymmetrical impact on each other in the studied period. The author had applied the GARCH DCC model for their analysis

\section{The data description}

For the analysis of co volatility and spillover effect in exchange rate data has been collected from the Federal Reserve Data Base. The data comprises daily basis for the period of 5 years from April 2012 to March 2017. For convenience the data of holiday and nontrading day has been removed, the total 1200 days of data has collected. The data has been converted in to the foreign exchange in term of countries own currency for each country. The converted data has been modified in to the return form.

Chinese Yuan.
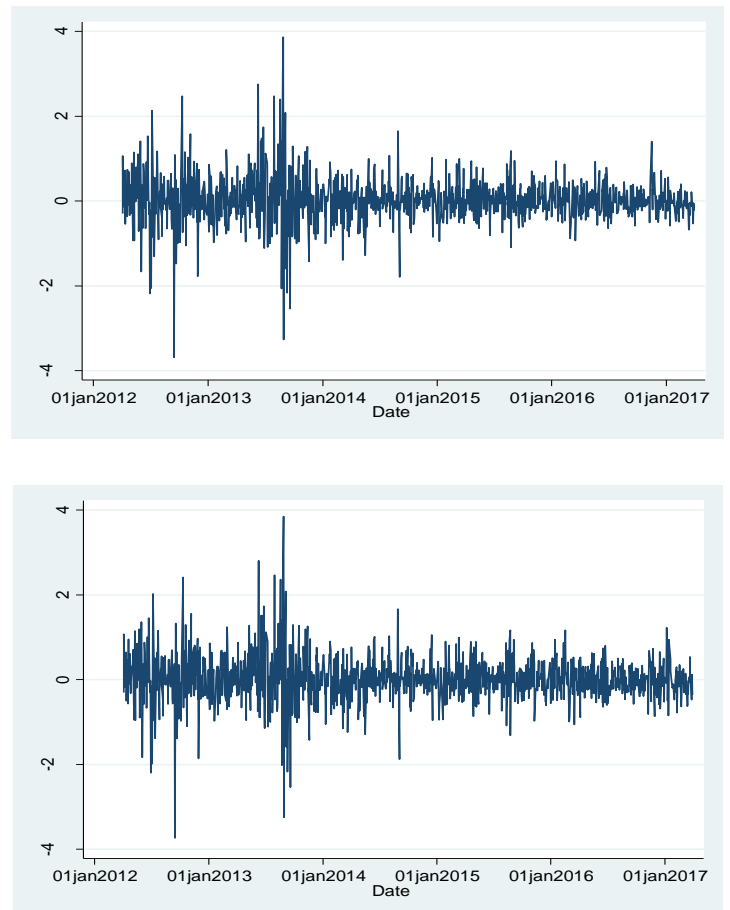

Fig. 1: Return Series in Indian Market US Dollar.
Malaysian Ringgit

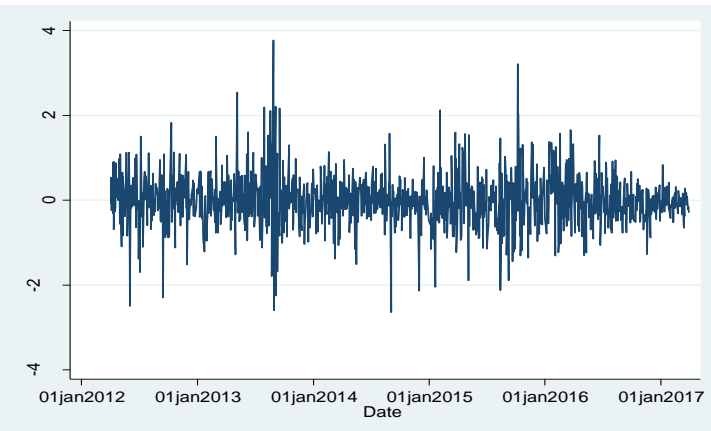

Fig. 2: Return Series in Chinese Market.

US dollar Indian Rupees.
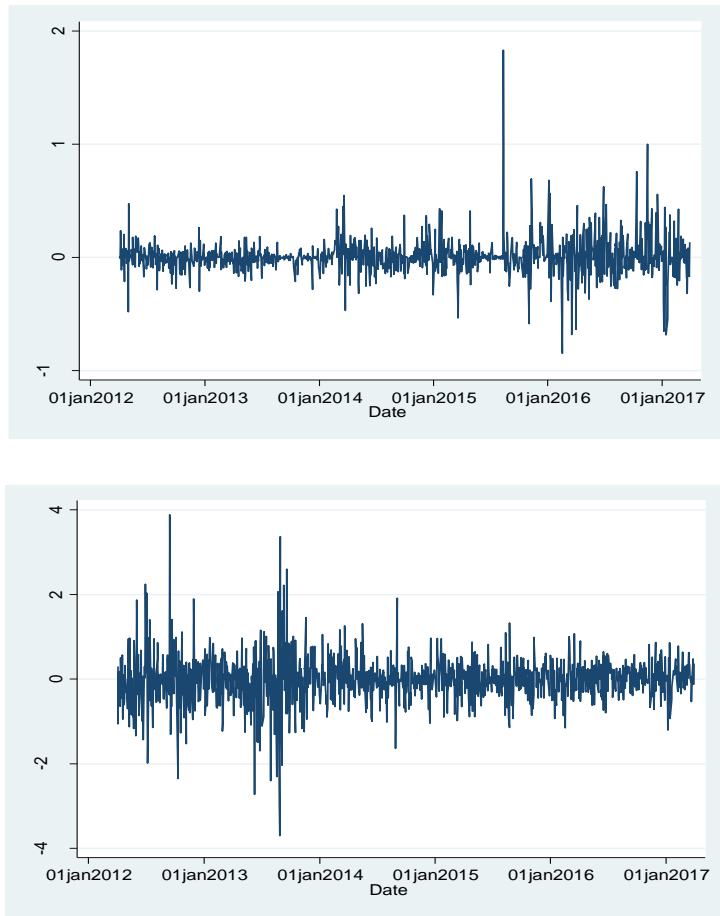

Malaysian Ringgit.

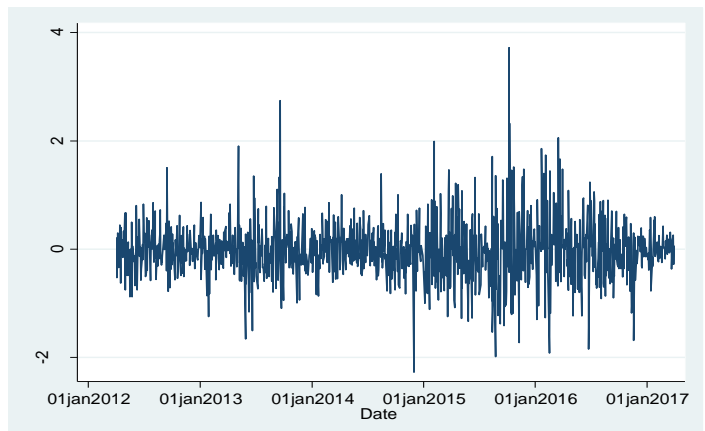

Fig. 3: Return Series in Malaysian Market.

US Dollar Indian Rupees. 

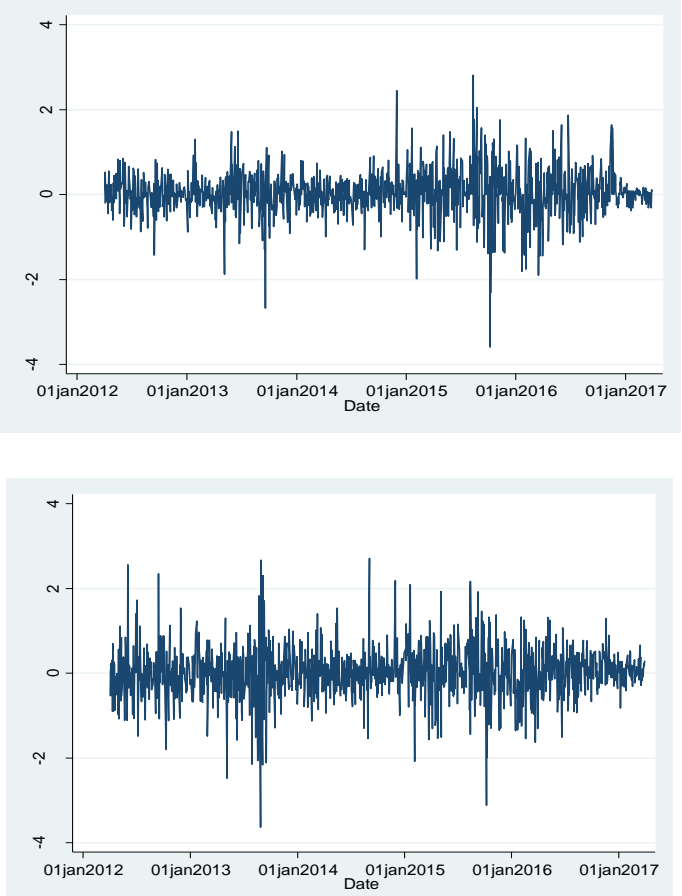

Chinese Yuan.

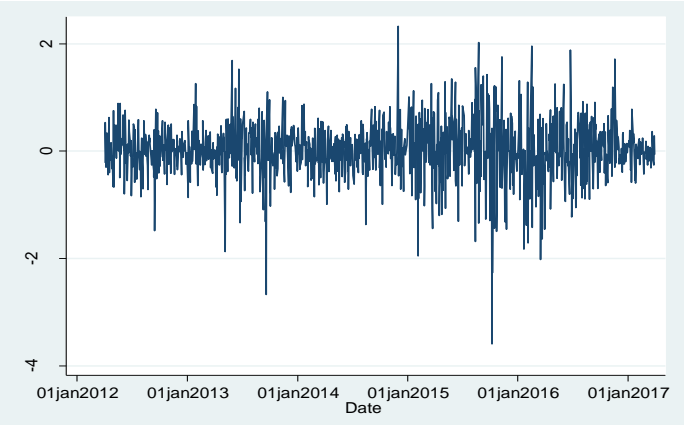

Table 1: Test of Unit Root of Above Variables

\begin{tabular}{|c|c|}
\hline Variables & $\mathrm{ADF}$ \\
\hline \multicolumn{2}{|c|}{ Indian FOREX market return on } \\
\hline US dollar (₹/\$) & $-30.734 *$ \\
\hline Chinese Yuan (₹/¥) & $-31.333 *$ \\
\hline Malaysian Ringgit (₹/RM) & -32.535 \\
\hline \multicolumn{2}{|c|}{ Chinese FOREX market return on } \\
\hline US dollar $(¥ / \$)$ & $-28.628 *$ \\
\hline Indian Rupees (¥/₹) & $-31.264 *$ \\
\hline Malaysian Ringgit (¥/RM) & $-33.633^{*}$ \\
\hline \multicolumn{2}{|c|}{ Malaysian FOREX market return on } \\
\hline US dollar $(\mathrm{RM} / \$)$ & $-32.039 *$ \\
\hline Indian Rupees (RM/₹) & $-32.535^{*}$ \\
\hline Chinese Yuan (RM/¥) & $-33.736^{*}$ \\
\hline
\end{tabular}

Note - $*$ is significant at $1 \%$ critical value.

The ADF test of stationary of data shows that all the variables in each market are highly stationary. Which is necessary for the building the volatility modeling.
Table 2: Descriptive Statistics of Above Variables

\begin{tabular}{|c|c|c|c|c|c|c|c|c|c|}
\hline & $\begin{array}{l}\text { (₹/ } \\
\$)\end{array}$ & (₹/¥) & $\begin{array}{l}(₹ / R \\
M)\end{array}$ & $\begin{array}{l}(¥ / \$ \\
\text { ) }\end{array}$ & $\begin{array}{l}\text { (¥/ } \\
₹)\end{array}$ & $\begin{array}{l}\text { (¥/ } \\
\text { RM } \\
\text { ) }\end{array}$ & $\begin{array}{l}(\mathrm{R} \\
\mathrm{M} / \$ \\
)\end{array}$ & $\begin{array}{l}(\mathrm{R} \\
\mathrm{M} / ₹ \\
) \\
\end{array}$ & $\begin{array}{l}(\mathrm{R} \\
\mathrm{M} / ¥ \\
)\end{array}$ \\
\hline $\begin{array}{l}\text { Mea } \\
n\end{array}$ & $\begin{array}{l}0.0 \\
21\end{array}$ & $\begin{array}{l}0.01 \\
4\end{array}$ & $\begin{array}{l}- \\
0.00 \\
8\end{array}$ & $\begin{array}{l}0.00 \\
7\end{array}$ & $\begin{array}{l}- \\
0.0 \\
1\end{array}$ & $\begin{array}{l}- \\
0.0 \\
22\end{array}$ & $\begin{array}{l}0.0 \\
3\end{array}$ & $\begin{array}{l}0.0 \\
12\end{array}$ & $\begin{array}{l}0.02 \\
4\end{array}$ \\
\hline $\begin{array}{l}\text { Std } \\
\text { dev }\end{array}$ & $\begin{array}{l}0.5 \\
4\end{array}$ & 0.55 & 0.61 & 0.15 & $\begin{array}{l}0.5 \\
5\end{array}$ & $\begin{array}{l}0.5 \\
3\end{array}$ & $\begin{array}{l}0.5 \\
2\end{array}$ & $\begin{array}{l}0.6 \\
1\end{array}$ & 0.52 \\
\hline $\begin{array}{l}\text { Kur- } \\
\text { tosis }\end{array}$ & $\begin{array}{l}11 . \\
41\end{array}$ & $\begin{array}{l}10.2 \\
5\end{array}$ & 6.66 & 25.3 & $\begin{array}{l}10 . \\
2\end{array}$ & $\begin{array}{l}7.2 \\
5\end{array}$ & $\begin{array}{l}7.7 \\
9\end{array}$ & $\begin{array}{l}6.5 \\
2\end{array}$ & 6.95 \\
\hline $\begin{array}{l}\text { Ske } \\
\text { wnes } \\
\text { s }\end{array}$ & $\begin{array}{l}0.1 \\
89\end{array}$ & 0.15 & 0.29 & 1.8 & $\begin{array}{l}- \\
0.0 \\
02\end{array}$ & $\begin{array}{l}0.5 \\
8\end{array}$ & $\begin{array}{l}- \\
0.3 \\
0\end{array}$ & $\begin{array}{l}- \\
1.8 \\
8\end{array}$ & $\begin{array}{l}- \\
0.49\end{array}$ \\
\hline $\begin{array}{l}\text { Jarqu } \\
\text { e } \\
\text { Bera } \\
\text { Test }\end{array}$ & $\begin{array}{l}306 \\
3 * \\
(0 . \\
00)\end{array}$ & $\begin{array}{l}4.2 \mathrm{e} \\
+04^{*} \\
(0.00 \\
)\end{array}$ & $\begin{array}{l}110 \\
4.9 \\
* \\
(0.0 \\
0)\end{array}$ & $\begin{array}{l}4.5 \mathrm{e} \\
+04 \\
* \\
(0.0 \\
0)\end{array}$ & $\begin{array}{l}311 \\
7.9 \\
* \\
(0 . \\
00)\end{array}$ & $\begin{array}{l}112 \\
6.3 \\
* \\
(0.0 \\
0)\end{array}$ & $\begin{array}{l}116 \\
4.8 \\
* \\
(0.0 \\
0)\end{array}$ & $\begin{array}{l}288 \\
6.0 \\
* \\
(0.0 \\
0)\end{array}$ & $\begin{array}{l}3.7 \mathrm{e} \\
+04 \\
* \\
(0.0 \\
0)\end{array}$ \\
\hline $\begin{array}{l}\text { Q } \\
\text { sta- } \\
\text { tis- } \\
\text { tics }\end{array}$ & $\begin{array}{l}50 \\
3 * *\end{array}$ & $\begin{array}{l}80.3 \\
* *\end{array}$ & $\begin{array}{l}76.3 \\
2^{* *}\end{array}$ & $\begin{array}{l}59.2 \\
*\end{array}$ & $\begin{array}{l}88 . \\
9 *\end{array}$ & $\begin{array}{l}67 . \\
5 * *\end{array}$ & $\begin{array}{l}95 \\
2^{*}\end{array}$ & $\begin{array}{l}76 . \\
4 * *\end{array}$ & $\begin{array}{l}85.2 \\
*\end{array}$ \\
\hline
\end{tabular}

Note - * is significant at $1 \%$ critical value.

The descriptive statistics of above variables shows that they are not normaly distributed. This things has been verified by the Jarque Bera Test. The coefficient of Jarque Bera Test is highly significant which reject the null hypothesis of normality of data. The value of kurtosis is not equal to 3 in any of the variables; the skewness value is also not equal to one in any case which gives the additional prove that data is not normally distributed. The portmanteau Q test shows that there is serial correlation in the return. We can see that $\mathrm{Q}$ statistics of all the variables are significant which reject the null hypothesis that residual of variables are not related. These findings also strengthen the fact that exchange rate volatility can be modeled in a GARCH framework. It can also inferred that the returns series of all the currencies exhibit nonrandomness and volatility clustering it means that large movements are characterized by large changes and vice-versa.

\begin{tabular}{|c|c|c|c|}
\hline Variables & chi2 & $\mathrm{P}$ value & conclusion \\
\hline $\begin{array}{l}\text { Indian FOREX market return } \\
\text { on } \\
\text { US dollar }(₹ / \$)\end{array}$ & $170.09 *$ & 0.000 & $\begin{array}{l}\text { ARCH effect } \\
\text { found }\end{array}$ \\
\hline Chinese Yuan (₹/¥) & $164.01 *$ & 0.000 & $\begin{array}{l}\text { ARCH effect } \\
\text { found }\end{array}$ \\
\hline Malaysian Ringgit (₹/RM) & $71.605^{*}$ & 0.000 & $\begin{array}{l}\text { ARCH effect } \\
\text { found }\end{array}$ \\
\hline $\begin{array}{l}\text { Chinese FOREX market re- } \\
\text { turn on } \\
\text { US dollar (¥/\$) }\end{array}$ & $49.863^{*}$ & 0.000 & $\begin{array}{l}\text { ARCH effect } \\
\text { found }\end{array}$ \\
\hline Indian Rupees (¥/₹) & $150.53 *$ & 0.000 & $\begin{array}{l}\text { ARCH effect } \\
\text { found }\end{array}$ \\
\hline Malaysian Ringgit (¥/RM) & $3.70 * *$ & 0.048 & $\begin{array}{l}\text { ARCH effect } \\
\text { found }\end{array}$ \\
\hline $\begin{array}{l}\text { Malaysian FOREX market } \\
\text { return on } \\
\text { US dollar }(\mathrm{RM} / \$)\end{array}$ & $3.25 * *$ & 0.046 & $\begin{array}{l}\text { ARCH effect } \\
\text { found }\end{array}$ \\
\hline Indian Rupees (RM/₹) & $72.15^{*}$ & 0.000 & $\begin{array}{l}\text { ARCH effect } \\
\text { found }\end{array}$ \\
\hline Chinese Yuan (RM/¥) & $4.39 * *$ & 0.0329 & $\begin{array}{l}\text { ARCH effect } \\
\text { found }\end{array}$ \\
\hline
\end{tabular}

Note - * is significant at $1 \%$ critical value and $* *$ is significant at $5 \%$ critical value.

For running the GARCH DCC model it is necessary that there should be an arch effect in the data. For confirming the ARCH effect we regress each of the variables and predict the residual of each variables. The squire of the residual has calculated and arch $\mathrm{lm}$ test has been done. the result of ARCH LM test revels that each variables there is arch effect is exist and that is desirable for the running the GARCH DCC model . The ARCH LM test shows that all the variables have ARCH effect. 


\section{Methodology}

The DCC-GARCH and Vector Autoregressive (VAR) Model. In the DCC model, the diagonal variable of $\mathrm{H}$ is modeled as GARCH models. The off-diagonal variables are modeled nonlinear functions of the diagonal terms:

$H_{i j, t}=\partial_{i j, t} \sqrt{H_{i i, t} H_{j j, t}}$

Where $\partial_{i j, t}$ Follows a dynamic process, rather than being constrained is constant as in the CCC specification. Two additional coefficients, $\lambda_{1}$ and $\lambda_{2}$ are adjustment parameters that govern the evolution of the conditional correlations. They must positive and sum to less than one. A test is sum of parameter is less than one or not. The sum is less than one is advocates the DCC model otherwise it goes to CCC model.

$\mathrm{Y}=\zeta x_{t}+e_{t}$

$e_{t}=\sqrt{H_{t}} v_{t}$

$H_{t}=\sqrt{D_{t}} R_{t} \sqrt{D_{t}}$

$R_{t}=\operatorname{diag}\left(Q_{t}\right)^{-1 / 2} Q_{t}\left(\operatorname{diag}\left(Q_{t}\right)^{-1 / 2}\right)$

$Q_{t}=\left(1-\lambda_{1}-\lambda_{2}\right) R+\lambda_{1} e_{t-1}+\lambda_{2} Q_{t-1}$

Where $D_{t}$ is a diagonal matrix of conditional variances, $R$ is is a matrix of conditional quasi-correlations, and $e_{t}$ is a vector of standardized residuals, $D_{t}{ }^{-1 / 2} e_{t}$. R is a weighted average of the unconditional VCE of the standardized residuals and the unconditional mean of $Q_{t}$. All the flexible versions of the MGARCH models are estimated under a multivariate Gaussian $t$ distribution as the normality assumption is rejected in most empirical applications.

For finding the spillover effect on the variables, the VAR model will be applied.

$y_{t}=\alpha+\sum_{i=1}^{n} \partial y_{t-i}+\varepsilon$

From above VAR model we can see that $y_{t}$ depend upon the pas lag of it past as well as the lag. $\alpha$ Is constant term where $\partial$ 's coefficients shows the relationship. $\varepsilon$ is white noise error term which is (iid). The variance decomposition can be find out once the above VAR model will be run to find out the spillover effect.

$y_{t}=\sum_{i=1}^{n} \partial_{i} \varepsilon_{t-1}$

Where $\mathrm{t}=1,2,3 \ldots \mathrm{Z}$ and $\partial$ is $N * N$ coefficient matrix and it follow a recursion of the form

$\partial_{i}=\theta_{1} \partial_{i-1}+\theta_{2} \partial_{i-2}+\cdots+\theta_{n} \partial_{i-n}$

And

$\partial_{0}=I_{n}$ and if $\partial_{1}=0$ for $i<0$

(KPPS hereafter) H-step-ahead forecast error variance decomposition is computed as

$\beta_{\mathrm{ij}}^{\mathrm{g}}(\mathrm{H})=\frac{\sigma_{\mathrm{ii}}^{-1} \sum_{\mathrm{h}=0}^{\mathrm{H}-1}\left(\mathrm{e}_{\mathrm{i}} \beta_{\mathrm{h}} \sum \mathrm{e}_{\mathrm{j}}\right.}{\sum_{\mathrm{h}=0}^{\mathrm{H}-1} \mathrm{e}_{\mathrm{i}} \beta_{\mathrm{h}} \sum \beta \mathrm{h} \mathrm{e}_{\mathrm{i}}}, \mathrm{i}, \mathrm{j}=1,2 \ldots . \mathrm{n}$

Where $\sum$ is variance matrix for the error vectore, $\sigma_{\mathrm{ii}}$ is standard deviation of the epsilon term of $\mathrm{i}^{\text {th }}$ variables and $\mathrm{e}$ is an $(\mathrm{n} * 1)$ vector with one as the ith element and 0 otherwise. To obtain a unit sum of each row of the variance decomposition, each entry of the variance decomposition matrix is normalized, so that construction the decomposition including own shocks in each market equal to one. According to the characteristics of generalized VAR, $\sum_{\mathrm{j}=1}^{\mathrm{n}} \beta_{\mathrm{ij}}^{\mathrm{g}}(\mathrm{H})$ is not equal to 1 , and then normalize each entry of the variance decomposition matrix by the row, as follows

$\beta_{\mathrm{ij}}^{\mathrm{g}}(\mathrm{H})=\frac{\beta_{\mathrm{ij}}^{\mathrm{g}}(\mathrm{H})}{\sum_{\mathrm{j}=1}^{\mathrm{n}} \beta_{\mathrm{ij}}^{\mathrm{g}}}$

Using these results, the spillover index is constructed as follow: Total spillover index.

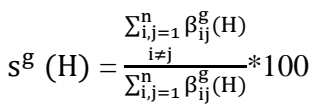

Where $\mathrm{i}=$ return in one Market and $\mathrm{j}=$ return in other different Market. The index measure the contributions from the spillovers of volatility shocks across return of asset to the total forecast error variance

\subsection{Directional spillovers}

The directional spillovers help us recognize both magnitude and the direction of the spillover effect the result of variance composition do not hinge on the sequence of the variable. The directional spillovers received by variable $i$ from all other variables $j$ are defined as

$S_{j \rightarrow i}^{g}(H)=\frac{\sum_{j=1}^{N} \beta_{i j}^{g}(H)}{i \neq j} * 100$

Where $\mathrm{i}=$ return of one Market and $\mathrm{j}=$ return of other Market. We can defined as return spillover effects, indicated the directional spillovers received by one country foreign exchange market from others countries Markets.

\section{Results and Interpretation}

We can see from the above result of GARCH DCC $(1,1)$ model.

Table 4: Cross Correlation in Indian FOREX Market

\begin{tabular}{ll}
\hline Variables & coefficient \\
\hline \multirow{2}{*}{ US dollar and Chinese Yuan } & $0.9603^{*}$ \\
& $(0.000)$ \\
Chinese Yuan and Malaysian Ringgit & $0.5315^{*}$ \\
Malaysian Ringgit and US dollar & $(0.000)$ \\
& $0.525^{*}$ \\
& $(0.000)$ \\
\hline
\end{tabular}

Table 5: Cross Correlation in Chinese FOREX Market

\begin{tabular}{ll}
\hline Variables & coefficient \\
\hline US dollar and Indian Rupees & $0.279^{*}$ \\
& $(0.000)$ \\
Indian Rupees and Malaysian Ringgit & $0.421^{*}$ \\
Malaysian Ringgit and US dollar & $(0.000)$ \\
& $0.1911^{*}$ \\
& $(0.000)$
\end{tabular}

Table 6: Cross Correlation in Malaysian FOREX Market

\begin{tabular}{lc}
\hline Variables & coefficient \\
\hline \multirow{2}{*}{ US dollar and Indian Rupees } & $0.604^{*}$ \\
& $(0.000)$ \\
Indian Rupees and Chinese Yuan & $0.950^{*}$ \\
Chinese Yuan and US dollar & $(0.000)$ \\
& $0.650^{*}$ \\
\end{tabular}




\begin{tabular}{llll}
\multicolumn{4}{c}{ Table 7: DCC Estimates } \\
\hline & $\begin{array}{l}\text { Indian FOREX } \\
\text { market return }\end{array}$ & $\begin{array}{l}\text { Chinese FOREX } \\
\text { market return }\end{array}$ & $\begin{array}{l}\text { Malaysian FOREX } \\
\text { market return }\end{array}$ \\
\hline$\alpha$ & $0.027^{*}$ & $0.0114^{*}$ & $0.049^{*}$ \\
$\beta$ & $0.9496^{*}$ & $0.9807^{*}$ & $0.896^{*}$ \\
$\alpha+$ & $0.9697^{*}$ & $0.991^{*}$ & $0.945^{*}$ \\
$\beta$ & Note - * is significant at 1\% critical value and ** is significant at 5\% criti- \\
cal value.
\end{tabular}

We Can see from the above result of GARCH DCC model that , the coefficient of $\alpha$ and $\beta$ are highly significant as well as their combined value is less than 1 in all the FOREX market which signifies the DCC model to be best fitted for the analysis.

USD v/s Yuan USD v/s Ringgit.
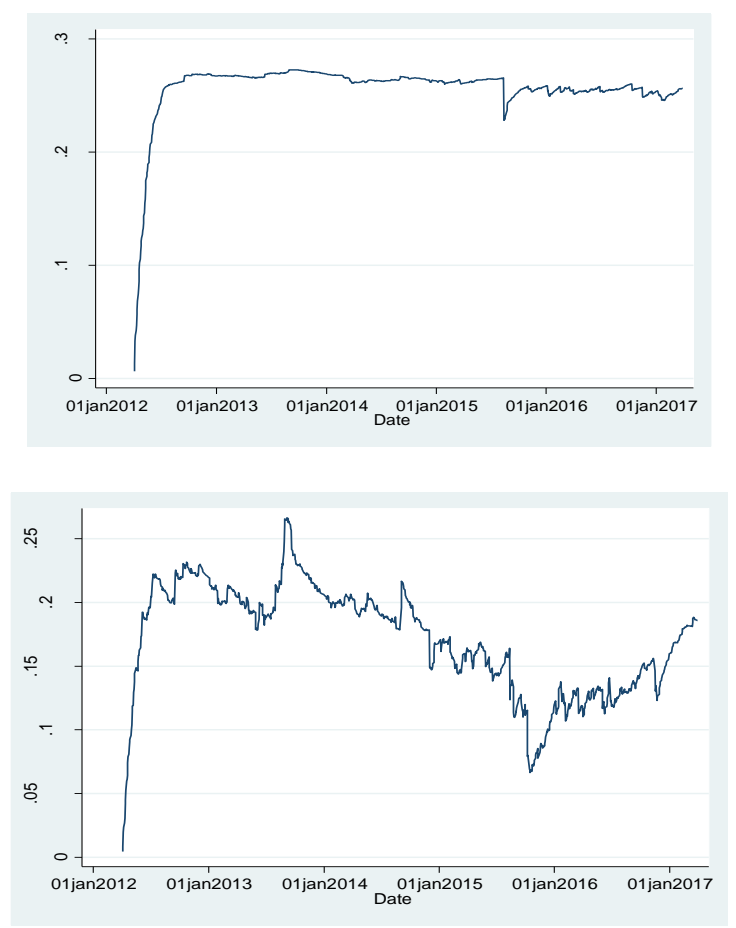

Yuan v/s Ringgit.

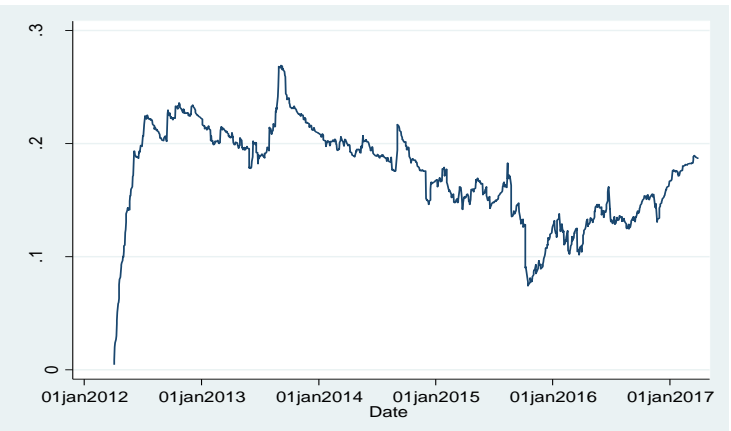

Fig. 4: Conditional Variance in Indian Market.

USD v/s Rupees USD v/s Ringgit.
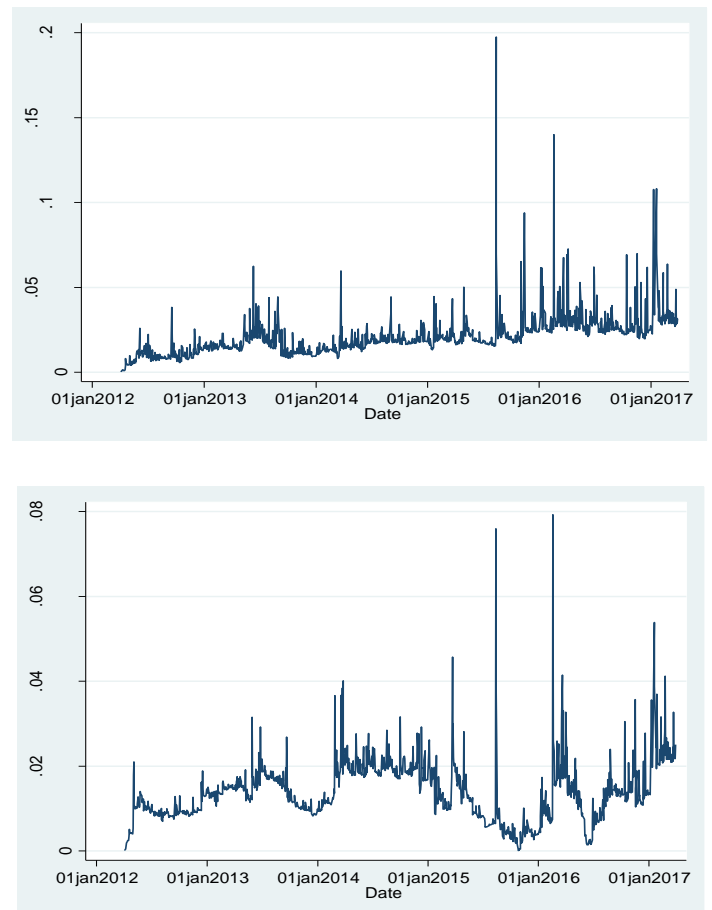

Rupees v/s Ringgit.

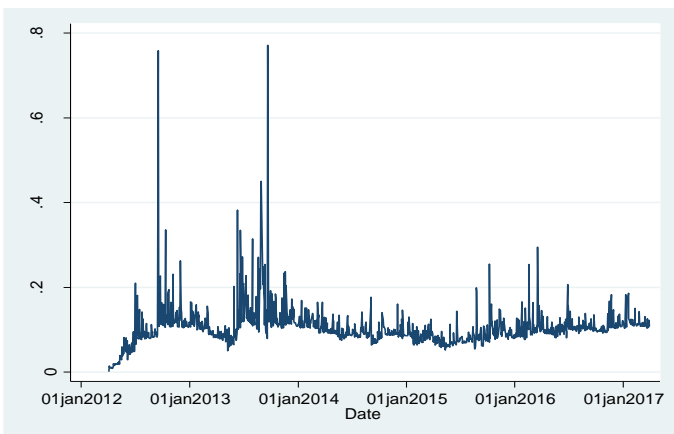

Fig. 5: Conditional Variance in Chinese Market.

USD v/s Yuan USD v/s Rupees.
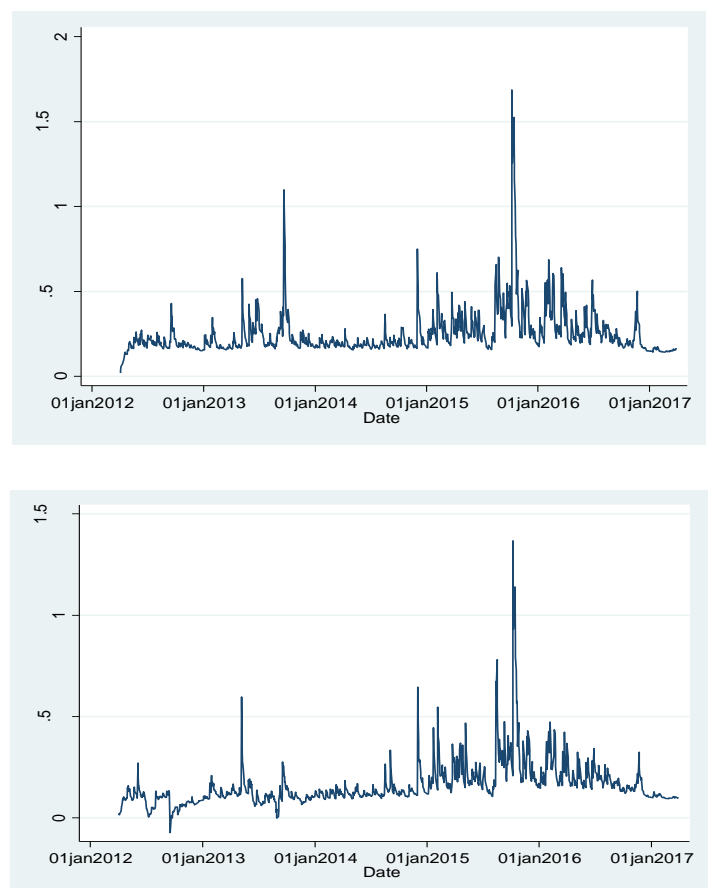

Yuan v/s Rupees. 


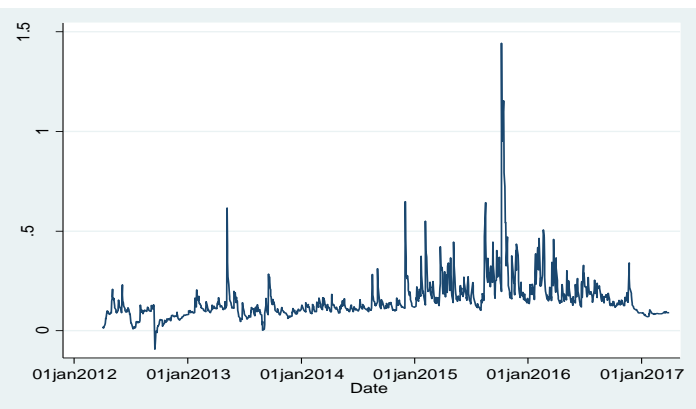

Fig. 6: Conditional Variance in Malaysian Market.

From above graph of conditional variance we can see that variability in Indian exchange rate is were high due to US dollar, Chinese Yuan and Malaysian ringgit in during the period of 2012 to 2013 After this period the volatility gets lower and lower after that. The conditional variance of Chinese FOREX market shows very low volatility from 2012 to end 2015. In December 2015 to Jan 2016 we can see that there was high volatility in Chinese FOREX market. The variance in exchange rate continues up and down till 2017 in Chinese exchange market. In Malaysian FOREX exchange market the conditional volatility is high in year of 2013 to 2014 and after that it gets lower, again in from November 2015 to January 2016 we can see that there were high volatility in Malaysian exchange market due to US dollar Indian rupees and Chinese Yuan.

Volatility Spillover

In this section it has been tried to find out the net spillover in each foreign exchange market. For this process vector auto regressive technique (VAR) has been used and variance decomposition has been utilized. The raw diagonal of the following tables shows that the $\%$ of variance in one currency has been explained by the other currency and the column of the table explain that \% variance in other currency has been explained by the particular currency. The last raw of the tables explain the total net spill over impact; either it is shock transmitter or shock observer.

Table 8: Volatility Spillover in Indian Forex Market.

From

To US dollar Chinese Yuan Malaysian Ringgit Contrib. from other US dollar 92.6 0.00 7.4 07.4

Chinese Yuan 22.6 73.4 4.00 26.6

Malaysian Ringgit 15.3108 .5976 .1023 .90

Contribution to other 37.9108 .5911 .4

Contribution

including own 130.5181 .9987 .5

Net spillover effect $30.51(-) 18.01(-) 12.5$

The VAR lag length of order 1 was selected by the HIC Criterion.

Table 8: Volatility Spillover in Chinese Forex Market

From

To US dollar Indian rupee Malaysian Ringgit Contrib. from other US dollar 1000.000 .000 .00

Indian rupee 5.9494 .060 .005 .94

Malaysian Ringgit 3.1910 .5186 .3013 .7

Contribution to other 9.1310 .510 .00

Contribution

including own 109.13104 .5786 .30

Net spillover effect $9.134 .57(-) 13.7$

The VAR lag length of order 1 was selected by the HIC Criterion.

Table 8: Volatility Spillover in Malaysian Forex Market

From

To US dollar Chinese Yuan Indian rupee Contrib. from other

US dollar 94.2 0.2 05.00 05.80

Chinese Yuan 12.0285 .252 .7314 .75

Indian rupee 05.636 .0088 .3711 .63

Contribution to other 17.656 .27 .73

Contribution

including own 111.8591 .4596 .1

Net spillover effect (+)11.85 (-) 8.55 (-) 3.9
The VAR lag length of order 1 was selected by the HIC Criterion. From above result we can see that in Indian and Malaysian foreign exchange market the US dollar seems as shock transmitter.US dollar explain almost 22\% volatility in Chinese Yuan and 15\% volatility of Malaysian ringgit in Indian exchange market. We can also infer that more than $12 \%$ volatility in Chinese Yuan and more that $5 \%$ volatility in Indian rupees have been explained by US dollar in Malaysian market. It means that US dollar has very strong influence in the Indian and Malaysian exchange rate market. As per as Chinese foreign exchange market s concerned, we can see the result that in this market the US dollar as well as Indian rupees has positive net spillover effect. The US dollar as well as Indian rupees are the net transmitter of shocks in Chinese market. We can also infer that the influence of US dollar in Chinese foreign exchange market s very low as compare to the Indian and Malaysian exchange rate market. In Chinese market Malaysian ringgit is net receiver of volatility

\section{Conclusion}

After the above empirical analysis it is concluded that there is volatility clustering exist in all the above three country FOREX market. The result of conditional variance shows that in Indian FOREX market conditional variance were high due to US dollar, Chinese Yuan and Malaysian ringgit in during the period of 2012 to 2013. After this period the volatility gets lower and lower after that. The conditional variance of Chinese FOREX market shows very low volatility from 2012 to end 2015. In December 2015 to Jan 2016 we can see that there was high volatility in Chinese FOREX market. The variance in exchange rate continues up and down till 2017 in Chinese exchange market. In Malaysian FOREX exchange market the conditional volatility is high in year of 2013 to 2014 and after that it gets lower, again in from November 2015 to January 2016 we can see that there were high volatility in Malaysian exchange market due to US dollar Indian rupees and Chinese Yuan. The result of volatility spillover effect shows that in Indian and Malaysian foreign exchange market the US dollar seems as shock transmitter. It means that US dollar has very strong influence in the Indian and Malaysian exchange rate market. We can also infer that the influence of US dollar in Chinese foreign exchange market is very low as compare to the Indian and Malaysian exchange rate market.

\section{References}

[1] Ahmed, M. (2012). Estimation of Exchange Rate Volatility via GARCH Model Case Study Sudan (1978 - 2009). International Journal of Economics and Finance, 4 (11), 183192.

[2] Anuradha Patnaik (2013), A Study of Volatility Spillover across Select Foreign Exchange Rates in India Using Dynamic conditional Correlations. Journal of Quantitative Economics, Vol. 11 Nos.1\&2 (Combined), January-July 2013

[3] Badrinath, H.R., Apte, P.G., (2005), "Volatility Spillovers Across Stock, Call Money And Foreign Exchange Markets", Unpublished, $1-26$.

[4] Bauwens, L., S. Laurent and J. V. K. Rombouts (2006), „Multivariate GARCH Models: A Surveye, Journal of Applied Econometrics, 21 79-109. https://doi.org/10.1002/jae.842.

[5] Behera, H. K. (2011), „Onshore and Offshore Market for Indian Rupee: Recent Evidence on Volatility and Shock Spillover"e, Macroeconomics and Finance in Emerging Market Economies, 4 (1) 43 55. https://doi.org/10.1080/17520843.2010.509918.

[6] Beine.M, S. Laurent and C. Lecount., (2003), "Official Central Bank Interventions and Exchange Rate Volatility: Evidence from a regime switching analysis", European Economic Review, Vol 47, Issue 5, 891-911. https://doi.org/10.1016/S0014-2921(02)00306-9.

[7] Hautsch, N. and Inkmann, J. (2003), "Optimal Hedging of the Currency Exchange Risk Exposure of Dynamically Balanced Strategic Asset Allocations", Journal of Asset Management, 4, 173-189. https://doi.org/10.1057/palgrave.jam.2240102.

[8] Hviding, K., M. Nowak and L. Ricci (2004). Can Higher Reserves Help Reduce Exchange Rate Volatility? International Monetary Fund Working Paper No.189. 
[9] Munazza Jabeen and Saud Ahmad Khan. (2011). Modelling Exchange Rate Volatility by Macroeconomic Fundamentals in Pakistan "International Econometric Review (IER)".

[10] Munandar \& C. Hafner, (2011), "The euro introduction and noneuro currencies", Applied Financial Economics, vol. 21(1-2), 95116. https://doi.org/10.1080/09603107.2011.523197.

[11] Nelson D.B. "Stationarity and persistence in the GARCH $(1,1)$ model," Econometric Theory 6, 1990: 318-334. https://doi.org/10.1017/S0266466600005296.

\section{Online papers}

1) Wann-Jyi Horng and Ju-Lan Tsai (https://www.cb.cityu.edu.hk/CONFERENCE/EMRM2012/doc/TS AI\%20Ju-Lan.pdf) by WJ Horng - Related articles. 